\title{
Identification of the Slovak traditional cheese "Parenica" microflora
}

\author{
MIROSLAVA KAČÁNIOVÁ 1,2 - MARGARITA TERENTJEVA ${ }^{3}$ - SIMONA \\ KUNOVÁ4 - L'UDMILA NAGYOVÁ 5 - ELENA HORSKÁ ${ }^{5}$ - PETER HAŠČÍK ${ }^{6}$ - \\ MACIEJ KLUZ² - CZESLAW PUCHALSKI² \\ 1Slovak University of Agriculture, Faculty of Biotechnology and Food Sciences, \\ Department of Microbiology, Nitra, Slovakia \\ ${ }^{2}$ Rzeszow University, Faculty of Biology and Agriculture, Department of \\ Bioenergetics and Food Analysis, Rzeszow, Poland \\ ${ }^{3}$ Latvia University of Life Sciences and Technologies, Faculty of Veterinary \\ Medicine, Institute of Food and Environmental Hygiene, Jelgava, Latvia \\ ${ }^{4}$ Slovak University of Agriculture, Faculty of Biotechnology and Food Sciences, \\ Department of Food Safety and Hygiene, Nitra, Slovakia \\ 5Slovak University of Agriculture, Faculty of Economics and Management, \\ Nitra, Slovakia \\ ${ }^{6}$ Slovak University of Agriculture, Faculty of Biotechnology and Food Sciences, \\ Department of Evaluation and Processing of Animal Products, Nitra, Slovakia \\ miroslava.kacaniova@gmail.com
}

\begin{abstract}
Summary
Numerous studies have demonstrated the higher accuracy, faster time-to-results and lower costs provided by MALDI Biotyper systems compared to classical methods. In this study, the culturable population of total count of bacteria, enterococci, coliforms bacteria, lactic acid bacteria (LAB) and microscopic fungi and yeasts from cow's dairy products was identified using the MALDI-TOF MS Biotyper. Altogether, 50 samples of the Slovak cheese "Parenica" were examined. Total numbers of bacteria were cultured on Plate count agar at $37^{\circ} \mathrm{C}$ for $24-48 \mathrm{~h}$, aerobically; enterococci were cultured on Enterococcus selective agar at $37^{\circ} \mathrm{C}$ for 24-48 h, aerobically; coliforms bacteria were cultured on Violet Red Bile lactose agar at $37{ }^{\circ} \mathrm{C}$ for $24-48 \mathrm{~h}$, aerobically. The LAB were cultured on MRS (Main Rogosa agar), MSE and APT agar at $30{ }^{\circ} \mathrm{C}$ in microaerophilic conditions. The microscopic fungi and yeasts were cultured on Malt extract agar at $25{ }^{\circ} \mathrm{C}$ for 5 days, aerobically. Isolated strains (total 669) were subjected to identification by the MALDI-TOF MS. Among total count the identified bacteria mostly were Acinetobacter baumannii, Bacillus cereus, Micrococcus luteus and Staphylococcus warneri. Escherichia coli and Enterobacter cloacae were the most abundant coliform bacteria representatives identified. Coliform bacteria included Citrobacter, Hafnia and Klebsiella. Altogether three genera belonged to the LAB - Lactobacillus, Lactococcus and Leuconostoc were identified with Lactococcus lactis, Lactobacillus plantarum, Lactobacillus coryniformis, L. fructivorans and Leuconostoc mesenteroides were considered as the dominated LAB species in dairy products. Among yeasts, Kluyveromyces lactis, Candida zeylanoides and Yarrowia lipolytica were among the most isolated.
\end{abstract}


Keywords: microorganisms, identification, MALDI TOF MS Biotyper, cow traditional cheese

\section{Introduction}

The main task of cheese microbiologists is to develop a clear view of the cheese microflora and its evolution during ripening. It is important that the complete flora is monitored and that the individual components are accurately identified and characterised (Beresford et al., 2001).

The indigenous flora of milk is the main factor affecting the specific consistency, aroma and flavour of raw milk cheese (Poznanski et al., 2004; Edalatian et al., 2012). Furthermore, the LAB, including wild type of cultures, represents a natural reservoir of microorganisms that contains diverse genetic information. Isolation and screening of LAB from natural processes have always been the most powerful means for obtaining useful cultures for commercial purposes. The use of commercial LAB cultures and pasteurized milk for industrial cheese production has led to the loss of flavour and a reduction in the diversity of dairy microflora. Sensorial differences between raw and pasteurized milk cheeses could be minimized by using LAB strains isolated from raw milk cheeses (Menendéz et al., 2004; Leboš Pavunc, 2012).

The reason for studying of the prevalence of enterococci in dairy products is the hygienic evaluation of the processing environment. The presence of enterococci has long been considered as a result of unhygienic conditions during the production and processing of milk. However, their presence in foods has often been shown to be unrelated with direct faecal contamination. Enterococci may enter the milk either directly from human or animal faeces or indirectly from contaminated water sources, exterior of the animal and/or from the milking equipment and bulk storage tank. Therefore, enterococci are a part of both the raw and pasteurised milk microflora. Different species of enterococci are found in dairy products, but E. faecalis and E. faecium remain the species of greatest importance (Franz et al., 1999; Gelsomino et al., 2001).

Coliforms were widely found in many cheeses (Brooks et al., 2012). However, in contrast to the presence of these microbes in raw and pasteurized fluid milk, and even in some other cultured products (e.g., yogurt), the presence of coliforms in cheese may be observed. The vast variety of types of cheese manufactured contributes to the complexity of fully understanding the role of coliforms in cheese quality and safety. Cheese product characteristics, including moisture content, $\mathrm{pH}$, salt content, ripening conditions, age of product, and culture all influence 
potential levels of and roles for coliforms and other microorganisms in the final product (Wolfe et al., 2014; Trmčič et al., 2016).

Molds and yeasts were recognized as an important cause of spoilage of various dairy products (Khalifa et al., 2013; Pal and Jadhav, 2013; Pal et al., 2014).The contamination of milk products with different types of fungi particularly of species of Aspergillus, Fusarium and Penicillium constitute a public health hazard as these fungi are known to produce mycotoxins that are injurious to human health (Pal, 2002; Sengum et al., 2008; Khalifa et al., 2013). Common contaminating yeasts of cheeses include Candida spp., Kluyveromyces marxianus, Geotrichum candidum, Debaryomyces hansenii and Pichia spp. (Johnson, 2001).

The conventional methods for identifying microorganisms in clinical microbiology laboratories are based on biochemical methods and gene sequencing identification techniques. However, these procedures take considerable time, and the results may be difficult to interpret occasionally because of indistinct reactions or outdated databases (Cherkaoui et al., 2010; Cloud et al., 2010). Recently, the matrix-assisted laser desorption/ionization time-of-flight mass spectrometry (MALDITOF MS) has been effectively used as a rapid method for identifying a wide array of microbial species (Croxatto et al., 2012; Patel, 2015).

The aim of this study was to identify the culturable population of total count of bacteria, enterococci, coliforms bacteria, lactic acid bacteria (LAB) and microscopic fungi and yeasts from cow's dairy products with MALDI-TOF MS Biotyper.

\section{Material and methods}

\section{Material}

In our study, 50 samples of the Slovak national cheese "Parenica" were examined. The cheese samples included non-smoked cheese $(n=25)$ and smoked cheese $(n=50)$. Additionally, 50 milk products samples from the western and middle parts of Slovakia directly from the producers (Bánovce nad Bebravou, Liptovský Mikuláš, Červený Kameň, Važec) were collected (Figure 1). Samples were kept sterilized sample containers and brought to laboratory with icebox for microbiological investigation.

Samples were stored at $4 \pm 1{ }^{\circ} \mathrm{C}$ until the testing began. The primary dilution of the milk products were made by adding of $5 \mathrm{~g}$ of sample material to $45 \mathrm{ml}$ of $0.9 \%$ sterile saline. Then, the serial dilutions $\left(10^{-1}\right.$ to $10^{-4}$ ) were done and $100 \mu \mathrm{l}$ of each dilution was plated out on to agars. 
Figure 1. Map of Slovak republic

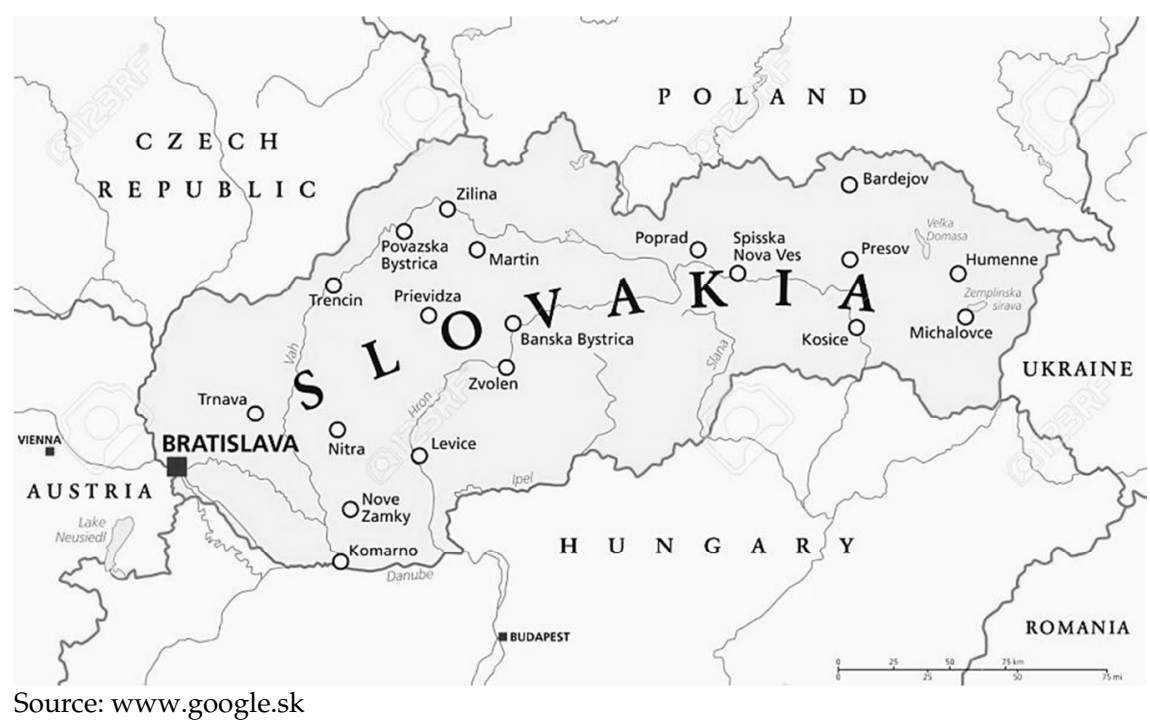

Methods

Isolation of total counts of bacteria

Plate count agar (PCA, (Sigma-Aldrich ${ }^{\circledR}$, St. Louis, USA) for total count bacteria enumeration were used. Inoculated plates were incubated for 24-48 $\mathrm{h}$ at $37^{\circ} \mathrm{C}$ and then examined for the presence of bacterial colonies.

Isolation of coliforms bacteria

Violet red bile lactose agar (VRBGA, Sigma-Aldrich ${ }^{\circledR}$, St. Louis, USA) for enumeration of coliforms bacteria were used. Inoculated plates were incubated for $24-48 \mathrm{~h}$ at $37^{\circ} \mathrm{C}$ and then examined for the presence of typical colonies.

Isolation of enterococci

Enterococcus selective agar (ESA, Sigma-Aldrich ${ }^{\circledR}$, St. Louis, USA) for enumeration of enterococci was used. Inoculated plates were incubated for $24-48 \mathrm{~h}$ at $37{ }^{\circ} \mathrm{C}$ and then examined for the presence of typical colonies.

Isolation of Lactic Acid Bacteria (LAB)

MRS (Main Rogose agar), MSE (Mayeux, Sandine and Elliker) for the detection and enumeration of Leuconostoc in milk and dairy products and APT (All Purpose TWEEN ${ }^{\circledR}$ Agar) for enumeration and cultivation of heterofermentative lactic acid bacteria including lactobacilli, leuconostocs 
and lactic acid streptococci as well as other microorganisms with high requirements for thiamine (Sigma-Aldrich ${ }^{\circledR}$, St. Louis, USA) agars were used for LAB identification. Inoculated plates were incubated for $72 \mathrm{~h}$ at $30{ }^{\circ} \mathrm{C}$ anaerobically and then the bacterial growth was evaluated.

Isolation of microscopic fungi and yeasts

Malt extract agar (Sigma-Aldrich ${ }^{\circledR}$, St. Louis, USA) and acid base indicator bromocresol green (Sigma-Aldrich ${ }^{\circledR}$, St. Louis, USA) $\left(0.020 \mathrm{~g} \mathrm{l}^{-1}\right)$ were used for microscopic fungi and yeasts identification. Inoculated plates were incubated for 5 days at $25^{\circ} \mathrm{C}$ aerobically and then the growth was evaluated.

\section{Identification of bacteria with MALDI-TOF MS Biotyper}

The suspicious colonies from total count of bacteria, coliforms bacteria, enterococci, lactic acid bacteria and fungi and yeasts were selected for further confirmation with MALDI-TOF. Selected colonies were cultured overnight on TSA agar (Tryptone Soya Agar) aerobically or anaerobically and used for identification.

A sample for analysis with MALDI-TOF MS analysis was prepared in accordance with extraction procedure provided by the manufacturer (Bruker Daltonik, Bremen, Germany). Bacterial colony was suspended in $300 \mu \mathrm{L}$ of water (Sigma-Aldrich, St. Louis, USA) and $900 \mu \mathrm{L}$ of absolute ethanol (Bruker Daltonik, Bremen, Germany), mixed and centrifuged at $13000 \mathrm{rpm}$ for $2 \mathrm{~min}$. After removal of supernatant, the pellet was mixed with $10 \mu \mathrm{L}$ of $70 \%$ formic acid (v/v) (Sigma-Aldrich, USA) and an equal volume of acetonitrile (Sigma-Aldrich, USA). The mixture was repeatedly centrifuged and $1 \mu \mathrm{L}$ of the supernatant was spotted onto a polished steel target plate and air dried at room temperature. Each sample was overlaid with $1 \mu \mathrm{L}$ of MALDI matrix (a saturated solution of a-cyano-4hydroxycinnamic acid, HCCA, Bruker Daltonik, Germany) in 50\% acetonitrile and $2.5 \%$ trifluoroacetic acid (Sigma-Aldrich, USA). Mass spectra were automatically generated using the microflex LT MALDITOF mass spectrometer (Bruker Daltonik, Germany) operated in the linear positive mode within a mass range of 2000-20000 Da. The instrument was calibrated using the Bruker bacterial test standard.

Results of mass spectra were processed with the MALDI Biotyper 3.0 software (Bruker Daltonik, Germany). The identification criteria used were: a score of 2.300 to 3.000 indicated highly probable identification on species level; a score of 2.000 to 2.299 secure genus identification with probable species identification; a score of 1.700 to 1.999 probable identification to the genus level; $<1.700$ was considered as unreliable identification. 


\section{Results and discussion}

The number of microorganisms in non-smoked cheese samples are shown in Figure 2. Total count of bacteria in non-smoked cheese ranged from 3.15 to $3.58 \mathrm{log} \mathrm{cfu}^{-1}{ }^{-1}$. Enterococci were not identified in the samples studied. Coliform bacteria counts ranged from 1.12 to $1.52 \log$ cfu.g- ${ }^{-1}$, but lactic acid bacteria counts ranged from 2.12 to 2.51 log cfu. $\mathrm{g}^{-1}$. Microscopic filamentous fungi and yeasts counts ranged from 1.12 to 1.54 $\log$ cfu.g-1.

Figure 2. Number of isolated microorganisms in non-smoked cheese

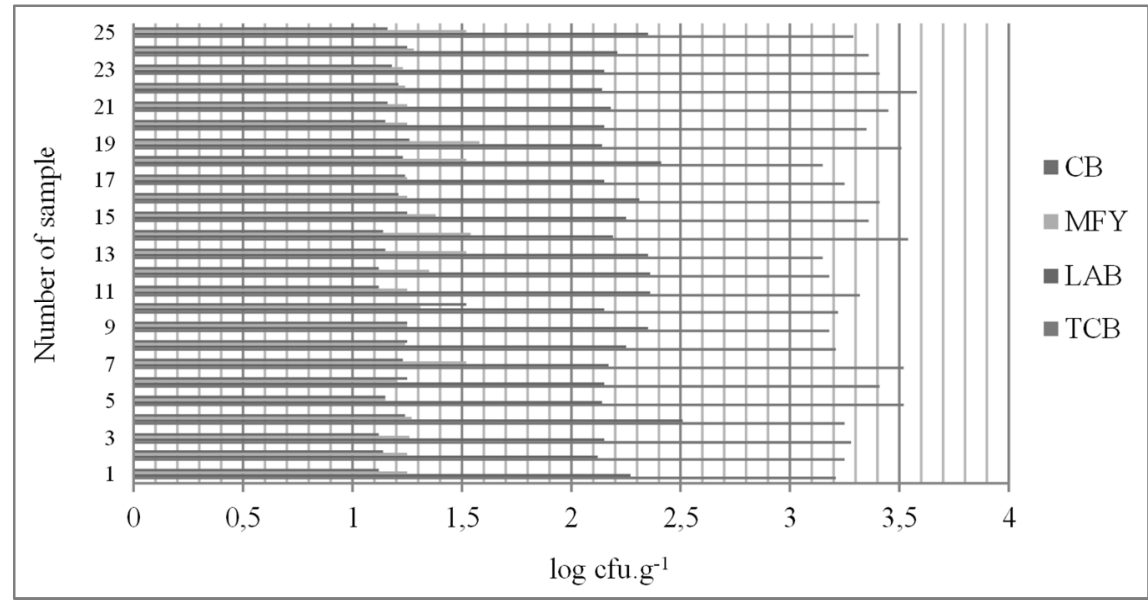

Note: TCB - total count of bacteria, LAB - lactic acid bacteria, MFY - microscopic filamentous fungi and yeasts.

Many types of fermented foods arex produced throughout the world. Fermentation improves the shelf life of these products and contributes to their typical sensory and nutritional properties. Cheeses are fermented dairy products whose manufacturing involves different types of bacteria, yeasts, and molds (Montel et al., 2014; Irlinger et al., 2015). Cheese manufacturing can be considered as a process in which a nutrient-rich environment, milk, is colonized by adventitious and deliberately inoculated microorganisms. Two different habitats may be considered, the interior of the cheese and the cheese rind. The rind microbiota can be considered as an interesting model system for the field of ecosystems biology (Wolfe et al., 2014).

Mounier et al. (2006) showed that the microorganisms that developed on the cheese surface were an adventitious microflora from the cheese environment (brine, ripening shelves, and personnel) which rapidly outnumbered the commercial cultures. Several hypotheses have been 
advanced to explain these findings. These ripening cultures may be unfit for the cheese habitat, or negative interactions may occur between them and the adventitious microflora. Bacterial and yeast strains have also been selected for their antilisterial activity (Eppert et al., 1997; Maoz et al., 2003).

The number of microorganisms in smoked cheese samples are shown in Figure 3. Total count of bacteria in smoked cheese ranged from 2.14 to $2.58 \mathrm{log}_{\text {cfu.g }}{ }^{-1}$. Enterococci and coliforms bacteria were not identified in the samples studied. Lactic acid bacteria counts ranged from 1.12 to 2.18 $\log$ cfu. ${ }^{-1}$. Microscopic filamentous fungi and yeasts counts ranged from 1.12 to $1.54 \log$ cfu.g ${ }^{-1}$.

Figure 3. Number of isolated microorganisms in smoked cheese

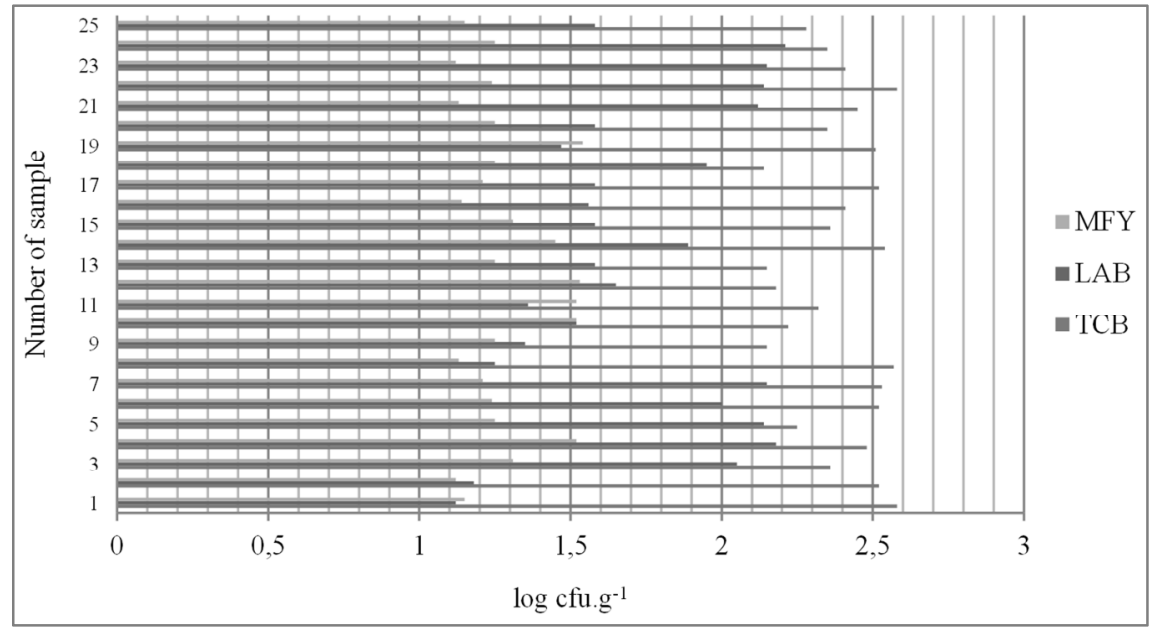

Note: TCB - total count of bacteria, LAB - lactic acid bacteria, MFY - microscopic filamentous fungi and yeasts.

From the non-smoked and smoked cheese a total of 47 species of 28 bacterial genera represented by 17 Gram-negative and 12 Gram-positive, and 10 species of yeasts belonging to 5 genera were identified with MALDI-TOF Mass Spectrometry. From a total of 669 isolates, the percentage representation of each microbial group reached the following values: 166 isolates of Gram-negative $(24.81 \%), 297$ isolates of Grampositive $(44.39 \%)$ and 206 isolates of yeasts (30.79\%). The most common microorganisms isolated from cheese are shown in Table 1. Yeast and bacteria were isolated from each sample. Bacterial species were identified in highest counts in comprasion with yeasts and fungi. 
At the beginning of the cheese-making process, lactic acid bacteria (LAB) starter cultures (i.e. Lactococcus lactis, Streptococcus thermophilus) grow rapidly and produce acid in milk (Delbes et al., 2007. During the first days of ripening, yeasts and/or moulds (i.e. Debaryomyces hansenii, Geotrichum candidum, Penicillium camemberti) colonize the surfaces of cheese and utilize lactate (Callon et al., 2006).

Table 1. Number of isolates identified with Maldi TOF MS Biotyper in cheese

\begin{tabular}{|c|c|c|c|}
\hline Microorganisms & $\begin{array}{c}\text { Non- smoked } \\
\text { cheese }\end{array}$ & $\begin{array}{c}\text { Smoked } \\
\text { cheese }\end{array}$ & Total \\
\hline \multicolumn{4}{|l|}{ Yeasts } \\
\hline Candida catenulata & 8 & 5 & 13 \\
\hline Candida famata & 8 & 5 & 13 \\
\hline Candida guilliermondii & 8 & 7 & 15 \\
\hline Candida kefyr & 8 & 5 & 13 \\
\hline Candida lusitaniae & 10 & 5 & 15 \\
\hline Candida zeylanoides & 19 & 15 & 34 \\
\hline Kluyveromyces lactis & 20 & 15 & 35 \\
\hline Saccharomyces cerevisiae & 10 & 8 & 18 \\
\hline Torulaspora delbrueckii & 10 & 7 & 17 \\
\hline \multirow[t]{2}{*}{ Yarrowia lipolytica } & 18 & 15 & 33 \\
\hline & 119 & 87 & 206 \\
\hline \multicolumn{4}{|l|}{ Gram-negative bacteria } \\
\hline Acinetobacter pittii & 3 & 2 & 5 \\
\hline Acinetobacter baumannii & 15 & 10 & 25 \\
\hline Acinetobacter junii & 3 & 2 & 5 \\
\hline Chryseobacterium oranimense & 4 & 5 & 9 \\
\hline Citrobacter braakii & 5 & 0 & 5 \\
\hline Citrobacter youngae & 3 & 0 & 3 \\
\hline Enterobacter cloacae & 4 & 3 & 7 \\
\hline Escherichia coli & 25 & 5 & 30 \\
\hline Ewingella americana & 2 & 2 & 4 \\
\hline Gluconobacter cerinus & 5 & 5 & 10 \\
\hline Hafnia alvei & 8 & 1 & 9 \\
\hline Pantoea agglomerans & 2 & 5 & 7 \\
\hline Pluralibacter gergoviae & 3 & 2 & 5 \\
\hline Pseudomonas rhodesiae & 1 & 4 & 5 \\
\hline Rahnella aquatilis & 3 & 1 & 4 \\
\hline Raoultella ornithinolytica & 3 & 0 & 3 \\
\hline Raoultella planticola & 2 & 1 & 3 \\
\hline Rhizobium radiobacter & 2 & 3 & 5 \\
\hline Serratia liquefaciens & 5 & 0 & 5 \\
\hline Sphingomonas melonis & 5 & 5 & 10 \\
\hline \multirow[t]{2}{*}{ Sphingomonas parapaucimobilis } & 5 & 2 & 7 \\
\hline & 108 & 58 & 166 \\
\hline
\end{tabular}

The rest of Table 1 is on the next page ... 
... second part of Table 1

\begin{tabular}{|c|c|c|c|}
\hline Microorganisms & $\begin{array}{l}\text { Non- smoked } \\
\text { cheese }\end{array}$ & $\begin{array}{c}\text { Smoked } \\
\text { cheese }\end{array}$ & Total \\
\hline \multicolumn{4}{|l|}{ Gram-positive bacteria } \\
\hline Bacillus cereus & 20 & 12 & 32 \\
\hline Bacillus pumilus & 4 & 2 & 6 \\
\hline Bacillus thuringiensis & 1 & 2 & 3 \\
\hline Brevibacterium casei & 3 & 0 & 3 \\
\hline Enterococcus durans & 5 & 4 & 9 \\
\hline Enterococcus faecalis & 4 & 3 & 7 \\
\hline Enterococcus faecium & 5 & 5 & 10 \\
\hline Enterococcus italicus & 1 & 2 & 3 \\
\hline Kocuria kristinae & 2 & 2 & 4 \\
\hline Lactobacillus acidophilus & 2 & 0 & 2 \\
\hline Lactobacillus coryniformis & 12 & 12 & 24 \\
\hline Lactobacillus curvatus & 5 & 5 & 10 \\
\hline Lactobacillus fermentum & 8 & 9 & 17 \\
\hline Lactobacillus plantarum & 10 & 10 & 20 \\
\hline Lactobacillus fructivorans & 10 & 10 & 20 \\
\hline Lactococcus lactis & 20 & 19 & 39 \\
\hline Leuconostoc mesenteroides & 15 & 10 & 25 \\
\hline Macrococcus caseolyticus & 2 & 3 & 5 \\
\hline Micrococcus luteus & 2 & 0 & 2 \\
\hline Pediococcus pentosaceus & 5 & 2 & 7 \\
\hline Staphylococcus epidermidis & 3 & 2 & 5 \\
\hline Staphylococcus haemoliticus & 2 & 4 & 6 \\
\hline Staphylococcus saprophyticus & 2 & 2 & 4 \\
\hline Staphylococcus succinus & 5 & 2 & 7 \\
\hline Staphylococcus warneri & 10 & 12 & 22 \\
\hline Streptococcus equinus & 1 & 1 & 2 \\
\hline \multirow[t]{2}{*}{ Streptococcus salivarius_ssp._thermophilus _ } & 2 & 1 & 3 \\
\hline & 161 & 136 & 297 \\
\hline Total & 388 & 281 & 669 \\
\hline
\end{tabular}

This leads to the deacidification of the cheese surface, enabling the establishment of a bacterial community which is less acid-tolerant (i.e. Arthobacter arilaitensis, Brevibacterium aurantiacum, Brevibacterium linens, Corynebacterium casei) (Belén Flórez and Mayo, 2006; Rademaker et al., 2006; Licitra et al., 2007; Parayre et al., 2007; Rea et al., 2007; Saubusse et al., 2007; Abriouel et al., 2008). Studies of traditional smear cheeses have also revealed the presence of moderately halophilic Proteobacteria i.e. Halomonas spp., bacteria from the Enterobacteriaceae family (i.e. Hafnia alvei), and halophilic and alkaliphic LAB i.e. Marinilactibacillus psychrotolerans or Alkalibacterium olivapovliticus. The roles of these organisms in cheese ripening have not yet been determined (Ishikawa et al., 2006; Mounier et al., 2009).

Cheese is a ready-to-eat food easily contaminated on the surface by undesirable microorganisms. Some are spoilage microorganisms which 
may produce uncharacteristic visual appearance and diminish the commercial value of the cheeses, such as Yarrowia lipolytica, Pseudomonas aeruginosa and Penicillium spp. but others are pathogenic such as Listeria monocytogenes, which have been associated with foodborne listeriosis by consumption of cheese (McLauchlin et al., 2004). The Gram-negative bacteria Pseudomonas spp. are the most important of the psychrotrophs that dominate in microflora of raw milk (Sorhaug and Stepaniak, 1997). Strains of Ps. aeruginosa have been associated with undesirable browning reactions on cheese rind, and some are pathogenic. The Y. lipolytica yeast, frequently found in cheeses, was also reported to be associated with browning phenomenon (Carreira et al., 1998). Mold Penicillium was the most frequently isolated from naturally contaminated cheese rind samples and include mycotoxigenic strains. All these microorganisms comprise strains with psychrotrophic characteristics that could increase in number during cold storage (Sorhaug and Stepaniak, 1997).

\section{Conclusion}

Microbiological analysis of 50 cheese samples revealed the three main groups of microorganisms: 47 species of 29 bacterial genera (17 Gramnegative and 12 Gram-positive) and 10 species of yeasts belonging to 5 genera were identified with MALDI-TOF Mass Spectrometry. From a total of 669 isolates, the percentage representation of each microbial group reached the following values: 166 isolates of Gram-negative $(24.81 \%), 297$ isolates of Gram- $(44.39 \%)$, and 206 isolates of yeasts $(30.79 \%)$.

\section{Acknowledgement}

Work was supported by grants APVV-16-0244.

\section{References}

Abriouel, H.-Martín-Platero, A.-Maqueda, M.-Valdivia, E.-Martínez-Bueno, M. (2008): Biodiversity of the microbial community in a Spanish farmhouse cheese as revealed by culture-independent methods. International Journal of Food Microbiology. 127: 200-208.

Belén Flórez, A.-Mayo, B. (2006): PCR-DGGE as a tool for characterizing dominant microbial populations in the Spanish blue-veined Cabrales cheese. International Dairy Journal. 16: 1205-1210.

Beresford, T. P.-Fitzsimons, N. A.-Brennan, N. L.-Tim, M. (2001): Recent advances in cheese microbiology. Cogan International Dairy Journal. 11: 259-274 
Brooks, J. C.-Martinez, B.-Stratton, J.-Bianchini, A.- Krokstrom, R.-Hutkins, R. (2012): Survey of raw milk cheeses for microbiological quality and prevalence of foodborne pathogens. Food Microbiology. 31. 154-158.

Callon, C.-Delbès, C.-Duthoit, F.-Montel, M. C. (2006): Application of SSCP-PCR fingerprint to profile the yeast community in raw milk Salers cheeses. Systematic Applied Microbiology. 29: 172-180.

Carreira, A.-Paloma, A.-Loureiro, V. (1998): Pigment producing yeasts involved in a brown surface discoloration of ewes' cheese. International Journal of Food Microbiology. 41: 223-230.

Cherkaoui, A.-Hibbs, J.-Emonet, S.-Tangomo, M.-Girard, M.-Francois, P. (2010): Comparison of two matrix-assisted laser desorption ionization-time of flight mass spectrometry methods with conventional phenotypic identification for routine identification of bacteria to the species level. Journal of Clinical Microbiology. 48: 1169-1175.

Cloud, J. L.-Harmsen, D.-Iwen, P. C.-Dunn, J. J.-Hall, G.-Lasala, P. R. (2010): Comparison of traditional phenotypic identification methods with partial $5^{\prime}$ 16S rRNA gene sequencing for species-level identification of nonfermenting Gram-negative bacilli. Journal of Clinical Microbiology. 48: 1442-1444.

Cogan, T. M. (2007): Stability of the biodiversity of the surface consortia of Gubbeen, a red-smear cheese. Journal of Dairy Sciences. 90: 2200-2210.

Croxatto, A.-Prod'hom, G.-Greub, G. (2012): Applications of MALDI-TOF mass spectrometry in clinical diagnostic microbiology. FEMS Microbiology Review. 36: 380-407.

Delbès, C.-Ali-Mandjee, L.-Montel, M. C. (2007): Monitoring bacterial communities in raw milk and cheese by culture-dependent and -independent 16S rRNA gene-based analyses. Applied Environmental Microbiology. 73: 1882-1891.

Edalatian, M. R.-Najafi, M. B. H.-Mortazavi, A.-Mayo, B. (2012): The biodiversity and evolution of lactic flora during ripening of the Iranian semisoft Lighvan cheese. International Journal of Dairy Technology. 65: 81-89.

Eppert, L.-Valdés-Stauber, N.-Gotz, H.-Busse, N.-Scherer, S. (1997): Growth reduction of Listeria spp. caused by undefined industrial red smear cheese cultures and bacteriocin-producing Brevibacterium linens as evaluated in situ on soft cheese. Applied Environmental Microbiology. 63: 4812-4817.

Franz, C. M. A. P.-Holzapfel, W. H.-Stiles, M. E. (1999): Enterococci at the crossroads of food safety? International Journal of Food Microbiology. 47. 124.

Gelsomino, R.-Vancanneyt, M.-Condon, S.-Swings, J.-Coga, T. M. (2001): Enterococcal diversity in the cheesemaking environment of an Irish Cheddartype cheesemaking factory. International Journal of Food Microbiology. 71: 177-188.

Ishikawa, M.-Kodama, K.-Yasuda, H.-Okamoto-Kainuma, A.-Koizumi, K.-Yamasato, K. (2006): Presence of halophilic and alkaliphilic lactic acid bacteria in various cheeses. Letters in Applied Microbiology. 44: 308-313.

Irlinger, F.-Layec, S.-Hélinck, S.-Dugat-Bony, E. (2015): Cheese rind microbial communities: diversity, composition and origin. FEMS Microbiology Letters. 362: 1-11. 
Johnson, M. E. (2001): Cheese products. [In: Marth, E. H.-Steele, J. L. (eds.) Applied dairy microbiology (Second edition).] New York: Marcel Dekker. 345-384.

Khalifa, M. I--Al-Ashmawy, M. A.-Abdel-Khalik, A.-El-Sherbini, M. (2013): Mycological evaluation of serving some dairy products with specific reference to mycotoxins production in Azhar University Student Hostels. World Journal of Dairy and Food Sciences. 8: 165-170.

Leboš Pavunc, A.-Beganovič, J.-Kos, B.-Uroič, K.-Blažič, M.-Šuškovič, J. (2012): Characterization and application of autochthonous starter cultures for fresh cheese production, Food Technology and Biotechnology. 50. 141-151.

Licitra, G.-Ogier, J. C.-Parayre, S.-Pediliggieri, C.-Carnemolla, T.-Falentin, H.-Madec, M. N.-Carpino, S.-Lortal, S. (2007): Variability of bacterial biofilms of the "Tina" wood vats used in the Ragusano cheese-making process. Applied Environmental Microbiology. 73: 6980-6987.

Maoz, A.-Mayr, R.-Scherer, S. (2003): Temporal stability and biodiversity of two complex antilisterial cheese-ripening microbial consortia. Applied Environmental Microbiology. 69: 4012-4018.

McLauchlin, J.-Mitchell, R. T.-Smerdon, W. J.-Jewell, K. (2004): Listeria monocytogenes and listeriosis: A review of hazard characterisation for use in microbiological risk assessment of foods. International Journal of Food Microbiology. 92: 15-33.

Menéndez, S.-Godinez, R.-Hermida, M.-Centeno, J. A.-Rodríguez-Otero, J. L. (2004): Characteristics of 'Tetilla' pasteurized milk cheese manufactured with the addition of autochthonous cultures. Food Microbiology. 21: 97-104.

Montel, M.-Buchin, C.-Mallet, S.-Delbes-Paus, A.-Vuitton, C.-Desmasures, N. (2014): Traditional cheeses: rich and diverse microbiota with associated benefits. International Journal of Food Microbiology. 177: 136-154.

Mounier, J.-Goerges, S.-Gelsomino, R.-Vancanneyt, R.-Vandemeulebroecke, K.-Hoste, B.-Brennan, N. M.-Scherer, S.-Swings, J.-Fitzgerald, G. F.-Cogan, T. M. (2006): The sources of the adventitious microflora of a smear-ripened cheese. Journal of Applied Microbiology. 101: 668-681.

Mounier, J.-Monnet, C.-Jacques, N.-Antoinette, A.-Irlinger, F. (2009): Assessment of the microbial diversity at the surface of Livarot cheese using culturedependent and independent approaches. International Journal of Food Microbiology. 133. 1-2: 31-37.

Pal, M. (2002): Mycotoxicoses: A global health problem. Beverage and Food World. 29: 34-38.

Pal, M.-Deressa, A.-Feleke, A.-Demissie, K. (2014): Hygienic and microbial quality control of butter. Beverage and Food World. 41: 37-38.

Pal, M.-Jadhav, V. J. (2013): Microbial contamination of various India milk products. Beverage and Food World. 40: 43-44.

Parayre, S.-Falentin, H.-Madec, M. N.-Sivieri, K.-Le Dizes, A. S.-Sohier, D.-Lortal, S. (2007): Easy DNA extraction method and optimisation of PCR-Temporal Temperature Gel Electophoresis to identify the predominant high and low GC-content bacteria from dairy products. Journal of Microbiological Methods. 63: 431-441. 
Patel, R. (2015): MALDI-TOF MS for the diagnosis of infectious diseases. Clinical Chemistry. 61: 100-111.

Poznanski, E.-Cavazza, A.-Cappa, F. P. S.-Cocconcelli, P. S. (2004): Indigenous milk microbiota influences the bacterial development in traditional cheese from an alpine natural park. International Journal of Food Microbiology. 92: 141-151.

Rademaker, J. L. W.-Peinhopf, M.-Rijnen, L.-Bockelmann, W.-Noordman, W. H. (2005): The surface microflora dynamics of bacterial smear-ripened Tilsit cheese determined by T-RFLP DNA population fingerprint analysis. International Dairy Journal. 15: 785-794.

Rea, M. C.-Goerges, S.-Gelsomino, R.-Brennan, N. M.-Mounier, J.-Vancanneyt, M.Scherer, S.-Swings, J.-Belén Flórez, A.-Mayo, B. (2006): PCR-DGGE as a tool for characterizing dominant microbial populations in the Spanish blue-veined Cabrales cheese. International Dairy Journal. 16: 1205-1210.

Saubusse, M.-Millet, L.-Delbès, C.-Callon, C.-Montel, M. C. (2007): Application of single strand conformation polymorphism-PCR method for distinguishing cheese bacterial communities that inhibit Listeria monocytogenes. International Journal of Food Microbiology. 116: 126-135.

Sengum, I.-Yaman, D.-Gonul, S. (2008) Mycotoxins and mold contamination in cheese. World Mycotoxicology Journal. 3: 291-298.

Sorhaug, T.-Stepaniak, L. (1997): Psychrotrophs and their enzymes in milk and dairy products: Quality aspects. Trends in Food Science and Technology. 8: 35-41.

Trmčić, A.-Chauhan, K.-Kent, D. J.-Ralyea, R. D.-Martin, N. H.-Boor, K. J. (2016): Coliform detection in cheese is associated with specific cheese characteristics, but no association was found with pathogen detection. Journal of Dairy Sciences. 99: 1-16.

Wolfe, B. E.-Button, J. E.-Santarelli, M.-Dutton, R. J. (2014): Cheese rind communities provide tractable systems for in situ and in vitro studies of microbial diversity. Cell. 158: 422-433. 